This is a pre-print of the following chapter: McBride, K., Misnikov, Y., Draheim, D, published in Scientific Foundations of Digital Governance and Transformation, edited by Charalabidis, Y., Flak, L. S., Pereira, G.V. 2021 Springer reproduced with permission of Springer. This preprint version will be updated to include the DOI when available.

\title{
Discussing The Foundations for Interpretivist Digital Government Research
}

Dr. Keegan McBride(a), Dr. Yuri Misnikov(b), Prof. Dr. Dirk Draheim(c)

a) Hertie School Centre for Digital Governance, Berlin, Germany. mcbride@ hertie-school.org

b) ITMO University Centre for e-Government Technologies, St. Petersburg, Russia.

c) Tallinn University of Technology, Information Systems Group, Tallinn, Estonia.

Abstract: As the research domain of digital government continues to develop itself as an important body of scholarly research, and it continues to grow in terms of researchers, publications, research funding, and other related indicators, it is important to understand the core theoretical and philosophical basis of the discipline. However, there is currently a lack of critical discussion about the concrete role of research philosophy for digital government research; which is one of the biggest current criticisms against the domain. This paper makes a first step in addressing this criticism by presenting arguments and discussion in favor of the importance of an interpretivist research philosophy for the domain of digital government. The paper provides a comprehensive overview of an interpretivist ontology and epistemology for digital government, discusses relevant theories and methods, and concludes with an overview of what is essential for conducting and carrying out interpretivist digital government research. This paper's contribution represents one of the first concentrated efforts to lay out some initial foundations for the role of interpretivism, and research philosophy more generally, for the field.

\section{Introduction}

There has been a rapid growth in the interest and study of digital government ${ }^{1}$, since it came into the mainstream in the 1990s. At its earliest stages, digital government (what was until recently known as e-Government) was viewed primarily as an object, or focus, of study with research on the topic being carried out in the study domains of either Public Administration (PA) or Information Systems (IS) research. However, as, interest in the topic began to grow, and the volume of research published on the topic grew, there was increased interest in whether or not digital government was truly just an area of research, or, rather, was it a domain on its own. Many authors and practitioners were in the former camp, rather than latter, pointing out that there was no, and will not be, a standalone domain known as "digital government". Jochen Scholl has pointed out that digital government "fails the test" as being a "legitimate" discipline as "there is no unifying theory or competing theories, no accepted standards of methods and procedures of inquiries have been established, and no shared vision of digital government Research's long-term impact has emerged" (Hans J Scholl, 2007 p. 26), furthermore claiming that there are no "structural elements on a university level, researcher self-identification with the discipline, [or] icons/visible leading scholars" (Hans. J Scholl, 2010 p. 17 citing Hans J Scholl, 2007). However, signs have begun to emerge that these criticisms have been and are currently being addressed.

Firstly, there has been an increased emphasis on obtaining definitional clarity about what "digital government" means. While, earlier on, definitions were techno-centric and often focused on specific technologies, such as the Internet or

\footnotetext{
${ }^{1}$ Though the area of research started with the name „e-Government“ there has been increased movement to refer to it now as ,digital government“. So, for this reason, this paper will use the term „digital government“. Though they are used colloquially to mean the same thing, fundamentally, e-Government is more commonly associated with „out-dated“ technologies and techno-centrism (e.g. email and the internet), whereas ,digital government“ is meant to be more all-encompassing and future-oriented, able to include new and rapid technological developments under its umbrella.
} 
email, what has become increasingly clear, is that technology changes, and, therefore, any definition of digital government must be able to account for this. Though there is still some ambiguity with the conceptual definition, what appears to be clear, is the importance of information: its availability and the flow of information between stakeholders (government, society, organizations, citizens) (McBride, 2020; Norris, 2010). Additionally, there have been new and targeted efforts towards theorizing on the nature of digital government, this can be seen with research tracks devoted specifically to this topic at leading digital government conferences. Furthermore, there are now devoted study programs to digital government, you can get a degree in the domain, there are funding opportunities specifically for scholars of digital government, academics do self-identify as scholars of digital government, it is possible to find lists of top digital government scholars (Apolitical, 2019; Hans J Scholl, 2016, 2014), there are numerous indices devoted to the study and ranking of digital government initiatives (such as Waseda IAC or UN EGDI), there is an agreed upon body of literature that can be described as belonging to the domain of digital government (the digital government reference library), there are digital government specific conferences, and there are digital government focused research centers. Thus, it can be argued, that there are, at the very least, clear markers that we are witnessing the development of a new stand-alone study domain.

Returning to the theorization of the field, one would expect that there would be a strong philosophical basis for research that focuses on understanding and interpreting complex digital government, especially due to the social and qualitative nature of digital government; however, this is not the case. In fact, one of the largest streams of criticisms against digital government research has been its positivist focus, lack of rigor, and attempting to explain phenomena without truly understanding (Heeks \& Bailur, 2007). Starting in 2007, Heeks and Bailur issued one of the earliest critiques of digital government, accusing the field of having "an arid monoculturalism" without any "role for research philosophy in e-Government research" (p. 251) with papers being techno-centric, ignoring evidence about negative aspects of technology, and contain a "naïve optimism [...] which simply seems to regard IT as a 'good thing' for government" (Heeks \& Bailur, 2007. p. 248). Continuing on, the authors note that digital government will largely remain underdeveloped because of "the absence of interpretivist or critical work" (Heeks \& Bailur, 2007. p. 251). In 2007, Mete Yildiz highlighted that the lack of definitional clarity and a focus or obsession on artifacts and outcomes in digital government was a significantly limiting factor for the potential usefulness of the field of digital government; one way to overcome this would be to focus on context and the complex environment associated with digital government (Mete Yildiz, 2007). Almost 10 years after Heeks and Bailur's critique of the digital government field, a study by Joseph, 2013 was published where it was found that 82 out of 103 papers used a positivist research approach (approximately $80 \%$ of analyzed papers) and approximately half of all papers were "conceptual or rely solely on secondary data sources" (Joseph, 2013. p. 439). More recently, taking up the call from these critical analyses of digital government research, Meijer and Bekkers authored a paper titled "A metatheory of e-Government: Creating some order in a fragmented research field" that attempted to generate a 'metatheory' of digital government and better understand the different theoretical and philosophical approaches to digital government research. The core findings here were that $87.9 \%$ of analyzed papers were positivist, with a focus on explaining digital government through the usage and creation of new theoretical models (Meijer \& Bekkers, 2015). It was further highlighted that a majority of the papers ignored the behavior, values, and beliefs of individual actors, and, rather focused more on 'holistic systems' 
(Meijer \& Bekkers, 2015). This makes sense, especially when taking into account that only $7.8 \%$ of studied papers utilized an interpretivist research philosophy (Meijer \& Bekkers, 2015), where the importance of individuals and social constructions is stressed.

Thus, digital government is in the situation where a large amount of research is being conducted, but there is room for improvement when it comes the theoretical and philosophical development of the field due to its current underdeveloped state. So, while the domain of digital government has excelled when it comes to creating change within government, development of models and frameworks, and trying to explain this process, it has left a large amount of research focused on generating true understanding untapped. This book chapter aims to address both this criticism of the domain of digital government and the lack of interpretivist research in the field by revealing and discussing the relevance of interpretivist research philosophy for digital government research; interpretivism is one of the core philosophical positions in the social sciences, and provides a solid base for interpreting and generating understanding about complex social phenomena.

This chapter represents one of the first concentrated efforts to provide an initial overview of interpretivist philosophy in regards of digital government and lays initial groundwork for future development of interpretivism as a digital government research paradigm. The chapter starts by providing an overview of common research philosophies, i.e., positivism, interpretivism, and pragmatism in Sect. 2. After this, it discusses the ontological and epistemological nature of interpretivism within the domain of digital government in Sect. 3, and continues on to discuss relevant interpretivist theories and methodologies in Sects. 4 resp. 5. Finally, the chapter will elaborate on some initial building blocks and ideas of interpretivist digital government in Sect. 6, on the basis of which more elaborate frameworks, guidelines, and best practices for conducting interpretivist digital government research might become possible. As a result of this work, this chapter should create a clear starting point for anyone who is interested in the philosophical underpinnings of the domain of digital government and for those who desire more insight and understanding about interpretivism more generally.

\section{Positivism, Interpretivism, Pragmatism and Ontology and Epistemology}

When it comes to research philosophy, the starting point is ontology. Taking the first dictionary definitions of the term, it can be seen that ontology is either "a branch of metaphysics concerned with the nature and relations of being" or "a particular theory about the nature of being or the kinds of things that have existence" (Merriam-Webster, 2020). Those from more technological domains may also have an understanding of ontology as "a set of representational primitives with which to model a domain of knowledge or discourse" (Gruber, 2009). In the context of philosophy, and more so related here to research philosophy, ontology can simply be understood as the core beliefs about the nature of reality, or, as discussed by Hay, 2011, “what's out there to know about?” (p. 169). Epistemology is highly dependent on ontology; in the context of a research philosophy, epistemology encapsulates what knowledge or understanding can be generated about a specific ontological reality. Finally, there is methodology, which mediates between ontology and epistemology, it is about the steps or processes that must be undergone in order to generate new understanding about the world. Every research philosophy will have some combination of these, each leading to a 
different and unique way of viewing the world, what constitutes reality, the sorts of knowledge that can be obtained, and how this knowledge can be gathered.

The first research philosophy to be presented will be positivism. Positivism aims at repeating the success of the scientific method of the natural sciences. Within the positivist paradigm, there is one true and objective reality, and this reality can be measured, studied, and understood via methodologically rigorous studies, the results of which are independent of the researcher. Positivist research aims to lead to the generation of testable and repeatable results, which eventually should lead to theories that allow researchers to make predictions or gain understanding about said objective reality. In concrete endeavors, positivist research is essentially deductive in nature; where, in order to assess hypotheses and theories, it often draws on quantitative methodologies. In other words, "positivists assume that reality is fixed, directly measureable, and knowable and that there is just one truth, one external reality" (Rubin \& Rubin, 2011. p. 14). Starting as early as in the 19th century with Auguste Comte and Émile Durkheim, positivism has now become a leading research philosophy within the social sciences. Consequentially, we find it also prominently in the fields of public administration, information systems, and digital government.

In contrast to positivism one would encounter the broader "anti-positivist" and "postmodern" philosophies, one of which is interpretivism. Interpretivism has become increasingly popular in social science inquiry, and is heavily related to the Weberian tradition of "verstehen" (Gregor, 2006; Schwandt, 1993). Verstehen is directly related to Max Weber's sociology and concerned with "how social actors understand themselves and their world" (Samier, 2005. p. 63 ) and "an abiding concern for the life world, for the emic point of view, for understanding meaning, and for grasping an actor's definition of a situation" (Schwandt, 1993. p. 221). In contrast to positivism, interpretivism trends toward inductive rather than deductive research, views reality as rather socially constructed, and is focused less on trying to identify an "objective" reality, but more on understanding and reconstructing how the subjects of the study have come to make the decisions that they did. Importantly, "interpretive approaches do not merely study beliefs, ideas or discourses. They study beliefs as they appear within, and even frame, actions, practices and institutions" (Bevir \& Rhodes, 2003. p. 17 cited in Hay, 2011). Which implies, then, that an interpretivist researcher would hold the belief that:

"To understand this world of meaning one must interpret it. The inquirer must elucidate the process of meaning construction and clarify what and how meanings are embodied in the language and actions of social actors" (Schwandt, 1993. p. 222)

Thus, when it comes to the epistemological aspects of interpretivism, it can be said that interpretivism views the generation of knowledge, understanding, and explanation as being inseparable from the researcher or the subject's lived experience. Methodologically, interpretivist research would cater towards methods such as hermeneutics, case studies, phenomenology, and discourse analysis (though there are numerous other applicable methods as well).

Somewhere in between positivism and interpretivism, but rather closer to the latter, is the idea of pragmatism. For pragmatists: "a theory for a pragmatist is true if and only if it is useful [...] Pragmatists are not looking for the essential and timeless truths of the positivists and logical empiricists" (Marshall et al., 2005). Pragmatism can trace its 
philosophical foundations to philosophers such as Charles S. Peirce and John Dewey (Wicks \& Freeman, 1998); it is empirical in nature, but "goes beyond a pure orientation to observation of a given reality" and is rather focused "towards a prospective, not yet realized world" (Goldkuhl, 2004. p. 13). In pragmatism, it is argued that the "meaning of an idea or a concept is the practical consequences of the idea / concept" (Goldkuhl, 2012. p. 139). Thus, in this way, pragmatism is slightly different than other philosophies in the sense that, action must come before theory, knowledge, or understanding, as it is only possible to attain these via action. Ontologically, pragmatism is focused on "actions and change; humans acting in a world that is in a constant state of becoming" (Goldkuhl, 2012. p. 139). In this sense, pragmatism lies somewhere in between the ontological extremes of positivism and interpretivism. Consequentially, when it comes to methodology, pragmatics often shows in the application of mixed-methods research. Epistemologically, pragmatism is primarily concerned with knowledge that allows it to enact change and believes that this knowledge can only be obtained through action. For this reason, methodologically, pragmatic research is highly focused on doing and would lend itself towards methods that encourage change and action, such as action research, design science, systems architecture and systems dynamics, as well as other methodological approaches focused explicitly on enacting change.

In order to demonstrate more clearly the differences between these research philosophies, Table 1 has been composed and highlights the core attributes and makeup of each.

Table 1 Comparison of Positivism, Interpretivism, and Pragmatism

\begin{tabular}{|l|l|l|l|}
\hline & Ontology & Epistemology & Methodology \\
\hline Positivism & Objective reality & $\begin{array}{l}\text { Knowledge is real and } \\
\text { objective, obtainable via } \\
\text { measurement and statistics } \\
\text { (reductionism ) }\end{array}$ & $\begin{array}{l}\text { Surveys, experiments, } \\
\text { statistical analysis }\end{array}$ \\
\hline Interpretivism & Subjective reality & $\begin{array}{l}\text { Knowledge is dependent } \\
\text { on beliefs, values, and } \\
\text { lived } \\
\text { (constructivism) }\end{array}$ & $\begin{array}{l}\text { Field studies, case studies, } \\
\text { hermeneutics, } \\
\text { phenomenology }\end{array}$ \\
\hline Pragmatism & Objective/subjective & $\begin{array}{l}\text { Knowledge is obtained by } \\
\text { doing and acting }\end{array}$ & $\begin{array}{l}\text { Mixed-methods research, } \\
\text { action research, design } \\
\text { science }\end{array}$ \\
\hline
\end{tabular}

\section{On the Ontological and Epistemological Nature of Digital Government}

In order to better ground the relationship between digital government and interpretivism, it is important to first start with a discussion about the nature of digital government and how it potentially relates to other already theoretically grounded concepts. Digital government is a good example of what Frank Webster (2014) defines as the 'generalizing terminology' that attempts to qualify a certain social, technical or economic construct or phenomenon, such as "preindustrial", "emerging democracy", "advanced capitalism", "authoritarian populism" (Webster, 2014, p.1). However, a curious scholar would also like to understand the meaning of the foundational term that describes the respective grand core concept, i.e., as "industrialism", "democracy", "capitalism", "totalitarianism", or, in the context of "digital 
government", the first question is what is "government". This is a necessary question to ask if one wishes to avoid being trapped in semantics and discussions about terms and definitions alone.

The notion of government belongs to an extensive domain of political philosophy and science scholarship, which is beyond the scope of this text. Yet, it is essential to discern its ontological origins in order to understand the theoretical foundations of digital government. In general terms, government is closely associated with the concept of "the state". Some commentators view it as a highly abstract concept, broader than the state itself and encompassing "political institutions through which political authority is exercised, such as the cabinet of ministers, parliament, courts of law, police, armed forces, and so forth" including rules, practices, institutions that guide the society's lives (Miller, 2003. p. 4). While others agree that the state is a 'conceptual abstraction', not a material object, and they tend to include government into the state itself, defining it as a set of governmental institutions responsible for "the process of making rules, controlling, guiding or regulating", which is synonymous with the elected officials in charge of public offices (Dunleavy \& O'Leary, 1987. p. 1), at least as far as modern Western liberal democracy is concerned. From this perspective, it is the organizational aspect of the state, which also includes the public service provision role. The state here is responsible for the "public system of rule" over societies within specific territories (King, 1986. p. 31). In effect, this narrower definition of government that is subordinated to the state in the form of a specialized organizational and functional apparatus is semantically similar to government viewed in broader institutional sense, as described above. We concur with this interpretation that theorizes the state rather than government, since it could provide a convenient entry point to conceptualize digital government as well. However, the available scholarship discussing theories of the state - and government, for that matter - do not appear interested in theorizing digital government from this political philosophy angle. For instance, such theories of the state as pluralism, corporatism, elitism, public choice, institutionalism, feminism, poststructuralism, green theory do not include digital government within their vocabulary_(Dunleavy \& O'Leary, 1987; Hay et al., 2006). This is a serious obstacle for theorizing digital government for scholars who may try to draw from political science foundations.

One closely related aspect to government, is that of governance, with state theorists claiming that there has been an ongoing shift from government to governance which diminishes the centrality of government in governing the society (Peters \& Pierre, 2006). This shift is marked by the expanding base of actors and networks, such as societal actors, that are becoming increasingly involved in the process of governing. The new governance theory claims that "the formal institutions of government have been largely replaced by the capacity of social actors such as networks and market to govern"; and this is due to the changed nature of operations of government in the newly changed governing conditions (Peters \& Pierre, 2006. p. 211). A similarly informed change has occurred also in the digital realm as civil society has become a stronger governance actor, with the term "e-Governance" spreading and being used to reflect upon a somewhat ambiguous relationship to the concepts of "e-Democracy" and "e-Participation". However, these concepts also suffer similarly from the same inadequate theorizing, as digital government does.

When it comes to the societal dimension of digital government in the state-society relationship, it appears better theorized from the information society viewpoint. The focus on the notion of 'information' in relation to 'society' is remarkably similar to the centrality of information in some of the current leading definitions of digital government. In 
some way, the term information society (or digital, e-society) is seen as a "new way of conceiving contemporary society" (Webster, 2014. p.2), thus invoking the inevitable analogy with the notion of digital government with its hope to radically change the state's modus operandi when it comes to public service provision by government institutions. When it comes to the theorization of information society, one can look to scholars such as Manuel Castells, Howard Rheingold, Frank Webster who are among the most prominent theorists (Castells, 1996, 1998, 2002; Rheingold, 1993; Webster, 2014). The striking feature of these scholars' works is the notable absence of discussing digital government in conceptual terms. For example, Frank Webster in his comprehensive review (and healthy critique) of the information society theories lists as many as nine related theories ${ }^{2}$, but none of them explicitly or implicitly include government or state related theories.

Thus, we arrive at a major conceptual disconnect when, on the one hand, theorizing the state (and/or government) does not account for the role of information technologies in general, and for digital government specifically, and, on the other hand, theorizing the information society, including its democratic aspects, demonstrates little interest in addressing the role of information in government; thus, scholars are left with either one side of the coin or the other, but never both. In consequence, theorizing digital government as a distinctive domain of scholarship struggles to draw on the existing conceptual foundations borrowed from government related theories or from those pertinent to society. There is also scarce evidence that digital government research has benefitted from a vast domain of Science and Technology (STS) studies either, which is a branch of study that focuses explicitly on the relationship between technology and society from a more constructivist or postmodern standpoint. In our view, these are serious foundational bottlenecks that make digital government research agenda less convincing in terms of its epistemic and heuristic value.

That being said, Frank Webster does offer some useful reasoning in his analyses of the information society theories that may be applicable in informing the conceptualization of digital government as well. He contrasts the roles of quantitative and qualitative changes of social systems that form the information society and he questions whether more information actually leads to an information society, arguing that it "is not that there is more information today (there obviously is), but rather that the character of information is such as to have transformed the way we live" (Webster, 2006, p. 9). In other words, it is not the amount of information that has changed us, but, rather the nature of information has changed, and has thus both changed and been changed by society. To understand what is being changed in social terms, and how the social change is being affected, one must account for the respective social actors and ask whether we already live in a fundamentally changed digital government. Is it different from the previous form of governing, or are we just witnessing an ongoing digitalization of the already established relationships? The answers to such questions could help accumulate some initial theoretical knowledge about digital government.

\footnotetext{
${ }^{2}$ These are: post-industrialism (represented by Daniel Bell); postmodernism (represented by Jean Baudrillard, Mark Poster, Paul Virilio); flexible specialization (represented by Michael Piore, Charles Sabel, Larry Hirschhorn); the information mode of development (represented by Manuel Castells); neo-Marxism (represented by Herbert Schiller); Regulation theory (represented by Michel Aglietta, Alain Lipietz); flexible accumulation (represented by David Harvey); reflexive modernization (represented by Anthony Giddens); the public sphere (represented by Jurgen Habermas, Nicholas Garnham).
} 
Building off of this, and in order to explain more specifically the ontological and epistemological nature of digital government research, which could help aid in answering such questions and improving the later theorization of the field, it is important as well to set out, concretely, some initial and fundamental beliefs on their nature. Ontologically speaking, it could be said that interpretivist digital government research is constructivist in nature, arguing that beliefs, traditions, and environmental contexts heavily influence our actions, and yet, do not determine them. Rather, this information provides actors with the necessary information to interact with others, make decisions, and overcome problems; furthermore, the actions taken may influence the beliefs, traditions, and environment. In practice, this would mean, that one would expect there to be a change in how digital government is understood across contexts and that so too the conceptualization will change as technology and society continues to development. Thus, it is the role of the interpretivist researcher to understand these interactions, how they influence and are influenced by each other, and how these interactions and exchanges bring digital government into reality. Epistemologically, interpretive digital government studies focuses on generating explanation through understanding. This requires an in-depth and an almost intimate knowledge of the context and environment where the given object of study takes place within, and the different beliefs, traditions, and values held by stakeholders involved in the process.

In order to generate this understanding, interpretivist digital government research would rely heavily on more qualitative methods, the nature of which are discussed further on in this chapter. Similarly, though interpretivist research tends to be inductive in nature, there are relevant theories for scholars who are looking to undertake interpretivist digital government research; these too are presented in this chapter.

\section{Interpretivist Digital Government Theory}

As one of the core aspects of a domain is related to the use and development of theory, it is important to highlight which theories would be compatible with and have been used for digital government research. When it comes to theory, there are a number of definitions that have been offered, but one simple proposal was put forth by Doty \& Glick, 1994, which states that, at a minimum, theory must: identify constructs, specify relationships between these constructs, and these relationships must be falsifiable (Gregor, 2006 citing Doty \& Glick, 1994). However, theory in the interpretivist paradigm is rather different in the sense that it focuses primarily on "understanding the complex world of lived experiences from the point of view of those who live it" (Schwandt, 1993. p. 221). Writing on a taxonomy of theories for information systems research, Gregor, 2006, highlighted five core types of theories: (T1) Analysis, (T2) Explanation, (T3) Prediction, (T4) Explanation and Prediction, and (T5) Design and Action. Relating back to Table 1, T1, T3, T4 would relate more closely to positivism and T2 would be associated with interpretivism; whereas (T5) would be associated, in first place, with pragmatism, although T5 can appear very well also with a positivist stance; and, sometimes also with an interpretivist.

As there is still a gap when it comes to explaining both how theories can and should be used for digital government research, and, furthermore, clarifying how these theories relate to their given philosophical paradigm, this section will introduce theories relevant to the conduction of interpretivist digital government research. While interpretivism is often viewed as, perhaps, theoretically inferior due to its emphasis on subjectivity, there are a number 
of theories (e.g. T2 theories) that are applicable for interpretivist research. For this chapter, we will present some of these relevant theories: Actor-Network Theory (ANT), Structuration Theory, and Technology Enactment Theory.

\subsection{Actor Network Theory}

Though ANT has not been used widely in digital government research, there are some examples of its use in the literature. One of the most known examples is a 2007 paper by Heeks \& Stanforth, 2007, who aimed to use ANT to understand a specific digital government development project that was taking place in Sri Lanka's Ministry of Finance. In this paper, the authors find that there are some limitations with the application of ANT to digital government, but, even still, note that their approach has allowed them to fight back against 'technological determinism' and also encompass many different perspectives and levels of analysis (Heeks \& Stanforth, 2007). ANT is highly valuable in that it places an "emphasis on the socio-technical middle ground" (Andrade \& Urquhart, 2010. p. 353); it "makes no analytical distinction between the social and the technical" (Stanforth, 2007, p.54); and views both human and non-human actors as having the same influence on a network (Heeks \& Stanforth, 2007).

ANT is a theory that is recognized for its unique approach to the world, viewing both technological objects, machines, and other technologies as conceptually having equal status of humans. It was developed initially by Michel Callon, Bruno Latour, and John Law - though most associate ANT with Latour - and views "the social and the technical as inseparable" (Walsham, 1997, p.467) and aims to understand how "relatively stable networks of aligned interests are created and maintained, or [why] such networks fail to establish themselves" (Walsham, 1997, p.469). In ANT, actors can be either social (humans) or technical (machines), so long as they influence the network. Networks are conceptualized differently than in other fields, with Latour highlighting that an "Actor-Network is an entity that does the tracing and the inscribing" and that "literally there is nothing but networks" (Latour, 1996, p.370-372). Another concept that needs to be understood is that of translation, which is how new Actor-Networks are created, via "a process of translating their interests to be aligned" (Walsham, 1997, p.468) and is often conceptualized as consisting of a fourstep process: 1) problematization; 2) interessement; 3) enrollment; and 4) mobilization (Callon, 1984). This concept of translation is also important to understanding the role of technology in ANT, as "technical objects participate in building heterogenous networks" and that these objects "define actants and the relationships between actants" (Akrich, 1992 p.206-207). When discussing digital government, which can be viewed as a complex socio-technical phenomenon (Lips, 2012, McBride \& Draheim, 2020), a holistic ecosystem comprising of an endless number of disparate components of both human and material nature, ANT may well be a useful theory. In general, while it is relatively easy to describe technological aspects of digital government by focusing on particular objects, it is almost impossible to capture its social side in the same way, thus, in this context, ANT might prove to be a useful theory to counteract this.

\subsection{Structuration Theory}

A second theory which is likely to be of high relevance for conducting interpretivist digital government research is that of "structuration theory" which underlines the significance of information in organizing social institutions through the process of "reflexive modernization" (Giddens, 1984, 1987). Structuration theory was 
conceptualized within the domain of sociology by Anthony Giddins and advances the core argument that "social structure exists in the actions of human agents as they use existing structures and create new ones in the course of everyday life" and that "structures exist as actors apply them" (Poole \& DeSanctis, 2011. p.6-7). Structuration theory is of an interpretive nature and provides a way of thinking about the world, in this sense it does not allow one to make predictions about the future, but, rather, provides a way for investigating and understanding a given object of study. Giddens' structuration theory would argue that, in the social sciences, "generalizations are necessarily historical" and that universal laws are likely impossible (Jones \& Karsten, 2008. p. 133). Studies that utilize structuration theory will be those that are more qualitative in nature and that offer the researcher the most room for interpretation, for example field work or case studies. When it comes to the application of structuration theory, it can be said that there are three primary structural dimensions (signification, domination, and legitimation), three methods of interaction (communication, power, and sanctions), and three modalities that link structure and interaction (interpretive schemes, facilities, and norms) (Jones \& Karsten, 2008 citing Giddens, 1984).

While structuration theory has found much use in Information Systems research, and may well be one of the most popular theories used in that field, it has not seen a large amount of usage for digital government research. However, in two separate accounts about the use of theory in the field of digital government (Bannister \& Connolly, 2015; Molnar et al., 2015), structuration theory was mentioned as being explicitly relevant for the domain. There has, additionally, been digital government specific research published using such theory. In Devadoss et al., 2003, structuration theory was used to explore the development and introduction of an e-procurement system, and, as a result of this analysis also began to put forth propositions about the structure digital government. In a separate paper, PuronCid, 2013 also used structuration theory, but in this instance conducted an embedded case study focused on a Mexican digital government project on IT-enabled budgeting.

\subsection{Technology Enactment Theory}

Technology Enactment (TE), is one of the first, and most influential, theories developed specifically with digital government in mind. TE and its framework first emerged in Jane Fountain's 2001 book titled "Building the Virtual State: Information Technology and Institutional Change". TE started from the understanding that theory was needed to increase understanding about the "deep effects of ICTs on organizational, institutional, and social rule systems in government which is not ordered by the invisible hand of the market" and, at its core, "emphasizes the influences of organizational structures (including 'soft' structures such as behavioral patterns and norms) on the design, development, implementation and use of technology" (Fountain, 2006. p. 153 - 154). TE is, by its nature, an interpretive theory that encourages scholars to understand how different rules, structures, values, beliefs, norms, etc. influence the use and development of technology in government organizations. In other words, it creates a set of guidelines that should help scholars to understand why the exact same technology may be used differently or have different effects in different contexts.

TE consists of five core aspects: objective information technologies, organizational forms, enacted technologies, outcomes, and institutional arrangements (J. Fountain, 2006). The theory then explores the relationships between these aspects. The theory has been used in digital government related research, but, it has also been subject to much criticism. In a work titled "Building the Virtual State . . or Not?" Donald F. Norris argues that TE is rather 
nothing new to scholars in public administration or information systems and is, rather, just a simple repackaging of socio-technical systems theory (Norris, 2003). There are also similarities to other theories such as institutionalism and Wanda Orlikowski's concept of "duality of technology" (which is also influenced by the aforementioned structuration theory). Though there is much to be said about the validity of this criticism, TE still represents one of the best attempts at creating theory for the domain of digital government, provides practical and relevant guidelines for investigating technologically-driven institutional change, and is clearly relevant for digital government scholars conducting interpretivist research.

\section{Interpretivist digital government Methodologies}

As methodology is used to mediate between ontology and epistemology, it is important to cover and discuss potential methodologies for interpretivist research. There are a number of different methodologies that have been utilized for digital government research, inclusive of both quantitative and qualitative methods. For example, papers may use structured literature reviews (Tursunbayeva et al., 2017), grounded theory (Lee \& Kim, 2007), case study research (Anthopoulos et al., 2016), survey (Ganapati \& Reddick, 2012), Delphi methodology (Niehaves, 2011), discourse analysis (M Yildiz \& Saylam, 2013), design science (Goldkuhl, 2016), TAM (Shyu \& Huang, 2011), UTAUT (Wang \& Shih, 2009), statistical analyses (Nam, 2014), and indeed a number of other methods, depending on the researchers' experiences and preferences, as well as the suitability for their given subject of research. While both quantitative and qualitative methods are used, it is argued here, that, from an interpretivist point of view, methods of the more qualitative nature are likely to be of use. While it is out of scope of this chapter to cover the entirety of relevant interpretivist methods, a small subset has been selected to provide an overview of what may well be some of the most relevant methods for conducting interpretivist research. The methods to be discussed in this chapter below are: case study research, discourse analysis, and grounded theory.

\subsection{Case Study Research}

The first method to discuss, is one that many authors are familiar with: case study research. There are a number of different approaches to case study research, such as those offered by Yin, Eisenhardt, or Merriam.

For Yin, a case study could be understood as "a contemporary phenomenon within its real life context, especially when the boundaries between a phenomenon and context are not clear and the researcher has little control over the phenomenon and context" (Yin, 2018) and is particularly appropriate when it comes to answering "how" or "why" questions (Yin, 2018). For Yin, a case study is something that can be methodologically rigorous, and can provide relevant empirical information when there is either a lack of theory or an under-exploration of a given phenomenon. Yin describes four primary forms of case studies, single or multiple-case design, with each option also allowing for either a single or multiple units of analysis; furthermore, Yin highlights that a case can be either descriptive, exploratory, or explanatory. While each aspect of case design and the type of case study selected is dependent on the goals of the research, what is common throughout, is the emphasis on data triangulation, academic rigor, and objectivity of the researcher. 
For Eisenhardt, a case can be understood as a "a research strategy which focuses on understanding the dynamics present within single settings" (Eisenhardt, 1989) and while Yin's work is primarily on case study design to ensure validity and rigor, her work is focused primarily on the use of case study research for the development of theory. In Eisenhardt's paper "Building Theories from Case Study Research", the author outlines and argues about the relevance and applicability of case study research for theoretical development. More specifically, the author notes that case study research for theory building may be ideal when there is "little known about a phenomenon, current perspectives seem inadequate because they have little empirical substantiation, or they conflict with each other or common sense" (Eisenhardt, 1989). When it comes to conducting the actual development of theory from case research, Eisenhardt proposes an eight-step process, namely: getting started, selecting cases, crafting instruments and protocols, entering the field, analyzing data, shaping hypotheses, enfolding literature, reaching closure (Eisenhardt, 1989). This sort of research is inductive and bottom-up in nature and more within the lines of an interpretivist philosophy than the approach argued for by Yin.

The third approach to case study research is that offered by Merriam, who has the most interpretivist approach to case work of the three authors presented here. Merriam views a case study as an "intensive description of a phenomenon or social unit such as an individual, group, institution, or community" (Merriam, 2002) and when it comes to case study research, it is the unit of analysis itself that defines the case, rather than the topic itself. Merriam argues that, as a result of this, case study research is often combined with other methods such as narrative analysis, grounded theory, or ethnographic studies (Merriam, 2002). When it comes to the core building blocks of case research, it could be said that there are three primary attributes: particularistic, descriptive, and heuristic (Merriam, 1998 cited in Yazan, 2015). In other words, a case needs to have a specific focus with a specific unit of analysis, much yield a "rich, thick description of the phenomenon" (Yazan, 2015 p. 139), and it must generate knew understanding about the object of study. Merriam's insistence on the importance of having a rich and thorough description of the case sets it apart from other case research, however, this emphasis on description and understanding also makes it of higher interest for interpretivist research.

Though there are different approaches and understandings to case study research, the scholars are also complementary in the sense that they provide a clear framework and approach for conducting case study research to achieve different aims, e.g., generating theory, exploration, description, explanation, etc. Additionally, in each instance, clear steps and effort is devoted to ensuring increased levels of internal and external validity, such as by ensuring triangulation of data, emphasizing the importance of description, clear data analysis protocols, offering clear frameworks for case analysis, and providing clear ways for the research to declare any potential subjectivity in the work.

In the current digital government research community, case based research is quite common, however, it often is missing direct links and ties to an interpretivist, or any, research philosophy. Although case study research more naturally lends itself to interpretivist research, it can appear anywhere on the positivism-interpretivism spectrum. For example, Robert Yin writes: "Much of case study research as it is described in this book appears to be oriented toward a realist perspective, which assumes the existence of a single reality that is independent of any observer. However, case study research also can excel in accommodating a relativist perspective [...] acknowledging multiple realities and 
having multiple meanings, with findings that are observer dependent." (Yin, 2018, "Ch. 1. Applicability of different epistemological orientations", para. 2) In the field of digital government, case studies rather often have a positivist perspective; then, this is typically paired with an optimistic technological determinism that is widespread in digital government research. Still, the elements of all three approaches described here are of great value for scholars to help anchor their research concretely within an interpretivist research paradigm, especially within the approach and context offered by Merriam.

\subsection{Critical Discourse Analysis}

Discourse analysis (DA) is a broad domain of critical discourse studies (CDS) that also includes critical discourse analysis (CDA). The DA qualitative research methods are widely applied across many disciplines in the social sciences and humanities, linguistics, media and communication studies, etc. The object of the analysis is any type of utterances - written and spoken texts, images, sign language. CDS examine the mutual relationship between semiotic structures and material institutions, which is relevant to digital governance focused on transmitting symbolic information between institutions and parties

CDA is a "problem-oriented interdisciplinary research programme" that focuses on "social phenomena, which are necessarily complex" and thus implies "a dialectical relationship between a particular discursive event and the situation(s), institution(s), and social structure(s) which frame it" (Wodak, 2014. p. 303). CDA is focused on understanding the constructive relationship between a given discourse and the relevant environmental societal factors that shape it, but, also, how those have been shaped by the discourse. CDA is commonly applied in social and qualitative research, but primarily in fields such as journalism or media studies. However, it also has a high relevance for scholars in the digital government community as it provides a clear and understandable approach to understanding topics or "discourses" that are currently relevant, such as "digital government", "information society", "digital Europe", or "open government". CDA claims that these discourses are influenced by societal or historical contexts, that these give the discourse meaning, and that the meaning ascribed to these discourses influence those who use them, as well as the institutions that shaped them.

In order to conduct CDA, Norman Fairclough provides a clear framework that consists of three primary dimensions: "the object of analysis [...] The processes by which the object is provided and received by human subjects [...] and the socio-historical conditions that govern these processes" (Janks, 1997. p. 329). Furthermore, each of these dimensions requires a separate sort of analysis, either description, interpretation, or explanation (respectively) (Janks, 1997). While this framework does not provide a methodology for analysis on its own, it does provide a clear way to frame CDA research. Methodologically, CDA can be seen as a four-step process: identifying an object of interest, understanding in which way society has influenced this object of interest, exploring the necessity or "inhereitness" of the object, and then providing a discussion on how to change the object of interest, if needed (Fairclough, 2013).

When it comes to the use of CDA in digital government explicitly, there is not a large volume of work. One paper, by M Yildiz \& Saylam, 2013, aimed to explore and understand core discourses that were associated with digital government; though it does not explicitly use CDA. As digital government is a rather new topic, it is important to 
understand the different ways in which its meaning has been and is currently being influenced by societal practices. In that work, the authors discuss a number of different identified discourses, and then further explain how these discourses influenced the ideas and actions of actors. Similarly, in a more recent paper, Draheim et al., 2020, did use CDA to identify core discourses and narratives in the field of digital government, identifying four main narratives that appear to influence the work of digital government scholars, namely: democratic, technocratic, tech-savvy, and implementation. What this provides, then, is a clear way to relate digital government research, with the beliefs and values that inform their beliefs as scholars.

CDA is likely to be of high interest and relevance for interpretivist digital government research as it provides a clear framework and approach to identifying the meanings and values associated with core phenomena in the field. Due to this, CDA may well also serve as a core starting point for native theoretical development in the field by providing the means to critically explore and understand the most basic and fundamental discourses, beliefs, and values associated with core constructs or phenomena within the field.

\subsection{Grounded Theory}

Grounded theory was started as a systematic programme in the late 1960s to complement a perceived mainstream of deductive social research. Glaser and Strauss, initiators of grounded theory, write: "Most writing on sociological method has been concerned with how accurate facts can be obtained and how theory can thereby be more rigorously tested. In this book we address ourselves to the equally important enterprise of how the discovery of theory from data - systematically obtained and analyzed in social research - can be furthered." (Glaser \& Strauss, 1967. p. 1). Grounded theory does not break with positivism completely, actually, it mediates between positivist, pragmatic and interpretivist positions: "Most important, it works - provides us with relevant predictions, explanations, interpretations and applications." (Glaser \& Strauss, 1967. p. 1). The interpretivist elements of grounded theory are significant, not to say dominant, which makes it fair to assign grounded theory to the realm of interpretive research. Still, positivist rigor is present in grounded theory, e.g., in making qualitative data analysis less informal. Methodologically, grounded theory essentially enacts a rigorous focus shift from testing theories (via deduced hypotheses) to generating theories, combined with several innovations and elaboration of best practices at the level of research techniques. Epistemologically, grounded theory shares the premises of Blumer's symbolic interactionism: (Blumer, 1969) (i) "human beings act toward things on the basis of the meanings of things have for them" (Blumer, 1969, p. 2), (ii) "the meaning of such things derives from the social interaction one has with one's fellows"(Blumer, 1969, p. 2); and (iii) "these meanings are handled in, and modified through, an interpretive process used by the person in dealing with the things he encounters." (Blumer, 1969, p. 2) This can be further compared with (Glaser \& Strauss, 1967) and (Aldiabat \& Le Navenec, 2011).

Qualitative data gains more importance in grounded theory, but quantitative data is also systematically considered. In service of qualitative data analysis, grounded theory elaborates a system of mutually dependent practices based on open, axial, selective coding (Strauss \& Corbin, 1998, pp. 55-242). Consequentially, also with respect to quantitative data, grounded theory elaborates an inductive strategy "that facilitates the generation of theory from quantitative data. 
It is a variation of Lazarsfeld's elaboration analysis of survey data (Lazarsfeld \& Rosenberg, 1955)" (Glaser \& Strauss, 1967, p. 186).

Grounded theory has been applied successfully in a series of digital government research endeavors. In Lee \& Kim, 2007, the authors conducted interviews with stakeholders of twenty-six government authorities interviewed to understand perceptions of digital government initiatives, in Reinwald \& Kraemmergaard, 2012, the authors reveal perceptions of stakeholders involved in a transformational government case study, and in Mergel et al., 2019, the authors exploit grounded theory to develop a framework for digital transformation in the public sector. The examples demonstrate the suitability of grounded theory for digital government research efforts.

\section{Overview of the Interpretivist digital government Research Process}

With the interpretivist digital government paradigm laid out in terms of ontology, epistemology, theory, and methodology, it is also important to highlight and outline what and how exactly interpretivist research may be conducted. It should be pointed out that there is not one "correct" way of doing interpretivist research, and this will vary depending on the selected methodology, but, there are some core "building blocks" that could be identified and serve useful as a starting point for interpretivist research.

The first step will be to identify a given object of study or a phenomenon of interest. With this object identified, the next step is to decide on the appropriate methodology. The next step, depending on the selected methodology, is to decide on the use of theory (if needed) and which theory to be used. As described by (Walsham, 1995), in interpretivist research, there is primarily three ways that theory is used: firstly, it could be used to help with the initial design of the search; secondly, it may be used during the actual analysis of the data itself; finally, it could be the actual result of the research itself. For example, if one was to be conducting grounded theory research, then it is imperative that no theory "is looked at" before the start of the research (the researcher needs to create awareness for any kind of bias stemming from knowledge of existing theories). In the case of other methods, for example case study research, it is dependent on the given situation how theory is to be used. With the research question and object of study identified, the methodology selected the process of research and interpretation can begin; a rough and abstract view of the core building blocks of this potential process is shown below as Figure 1.

\begin{tabular}{|c|c|c|c|c|c|}
\hline$\downarrow$ & $\downarrow$ & $\downarrow$ & $\downarrow$ & $\downarrow$ & \\
\hline $\begin{array}{l}\text { Identify Object of } \\
\text { Study }\end{array}$ & Context and History & Object of Study & $\begin{array}{c}\text { Beliefs about Object } \\
\text { of Study }\end{array}$ & $\begin{array}{c}\text { Examine the } \\
\text { Decisions Made }\end{array}$ & Interpretations \\
\hline
\end{tabular}

Figure 1 Interpretivist Research Building Blocks.

This figure shows six essential components of interpretivist digital government research: Identify Object of Study, Context and History, Object of Study, Beliefs about Object of Study, Examine the Decisions Made, and Interpretations. These components interact with each other through causalities as indicated by the arrows in Fig. 1. There is a dominating strand of causality between the components as indicated by the bold arrows, however, there exist potential feedback loops among and across all of the components, paying tribute to the highly iterative nature of research endeavors. 
Component 1 (Identify Object of Study): In the this component, the research identifies some sort of problem, current event, or other interesting phenomena that they wish to research or gain a better understanding of. In digital government research, this may include why or how digitalization has happened, why a certain project has or has not 'succeeded', or look comparatively between different digital government initiatives (this list, of course, is just a sample and not exhaustive).

Component 2 (Context and History): The second component is related to gathering an initial understanding about the unique context and history of the object of study. This can be done via desk work, field research, interviews, a survey, or some combination of other methods, but, what is important, is that a thorough, rich, and in-depth understanding must be gained about what contextual and historical factors may influence the object of study.

Component 3 (Object of Study): After this has been done, it is only then possible to research more the actual object of study. The idea here is to learn as much as possible about the concrete object being studied, what it is, how it happened, what are the important steps, who was involved, and other similar types of questions.

Component 4 (Beliefs about Object of Study): The next step is to understand stakeholders' beliefs about this object of study and then reflect back on how these beliefs have been influenced by and influence the context and history and also the object itself.

Component 5 (Examine the Decisions Made): Generally speaking, some decisions will have been made by individuals being studied, and these decisions have been influenced by their beliefs. These decisions and how the beliefs influenced them are key to gaining an understanding about the object being studied.

Component 6 (Interpretations): This is the result of the study, the interpretations. Here the researcher aims to demonstrate in a narrative or interpretive manner how the object of study unfolded or came into being, weaving together the previous five steps into a coherent argumentation that allows a reader to understand better the object being studied.

You can think of the components as forming a process. Such a process is malleable and can be adjusted based on a researcher's primary goals. However, taken as a process, it also provides clear guidelines and structure so that, when followed, other researchers would be able to both understand the validity of the research and also follow and agree with how primary researchers made their interpretations. As the process of interpretation is also subject to subjectivity, some efforts have been made by scholars to provide a list of criteria or guidelines that may well help to improve the validity and reliability of results for different interpretivist methodologies. For example, in Klein \& Myers, 1999, seven core principles for interpretivist field work are highlighted: the fundamental principle of the hermeneutic circle, the principle of contextualization, the principle of interaction between the researchers and the subjects, the principle of abstraction and generalization, the principle of dialogical reasoning, the principle of multiple interpretations, and the principle of suspicion (p. 72). While these principles were discussed in the context of field research, these core principles are applicable to other interpretivist methodologies a well. In a similar fashion, Butler, 1998 citing Madison, 1988 presents the importance of 10 key principles for conducting hermeneutic interpretivist research: coherence, 
comprehensiveness, penetration, thoroughness, appropriateness, contextuality, agreement (1), agreement (2), suggestiveness, and potential (p. 292).

Building off of these best practices, it is clear to see a number of important concepts for well-conducted interpretivist research. Firstly, the context that affected the research and which the research takes place in must be made clear to the reader, thus allowing for the interpretations and results of the research to be better understood. Secondly, acknowledge the subjective role of the researcher in the process, and present this to the reader. Thirdly, be thorough and concise, i.e., interpretive research requires rich, thorough, and comprehensive description, not only of the context, but of the process and phenomenon itself; the only way to ensure higher levels of internal and external validity of the research is via a thorough description. Fourthly, the interpretation should make sense; while this seems fairly straightforward, it implies that the interpretation can be backed up and supported by evidence; and, furthermore, if the proper context and description has been provided, it should be clear to others how this interpretation was made.

\section{Conclusion}

While digital government has, for the most part, remained under-theorized and under-philosophized, this book chapter has attempted to provide some initial input into rectifying this situation. Though this work simply aimed to start the discussion and make an initial contribution about the importance of interpretivist research for digital government scholars, it is hoped that, in the future, it could serve as a foundation for others who are interested in interpretivist digital government research. However, it is also important to note that while this chapter argues in favor of an interpretivist approach to digital government studies, this is not the only view, and, therefore, future research from scholars identifying and presenting the pragmatic and positivist philosophies of digital government would be of much benefit and interest for the field. While on its surface this chapter may appear to be rather oriented only towards students and scholars, there is likely to be a high level of relevance for other stakeholder groups, such as NGOs, policy makers, and other government officials as well. On the one hand, the chapter discussed core theories and methodologies related to digital government, the utilization and understanding of which, could help to drive certain changes in a given digital government-related context or could help to preemptively address and rectify negative or "unwanted" emergence behavior associated with a given digital government phenomenon.

In regard to the concrete contributions of this work, it is argued that there are primarily three. Firstly, the work provides an introduction and overview of the core ontological, epistemological, and methodological beliefs of positivist, interpretivist, and pragmatist research philosophies. Secondly, the paper provides a comprehensive theoretical and philosophical discussion about the interpretivist nature of digital government research, and clearly identifies potential anchoring points to ground it as a domain, and highlights how interpretivism may help solve the currently existing theoretical ambiguity. Finally, the work lays out a potential ontological and epistemological stance for interpretivist digital government research, discusses potential relevant theories and methodologies for such research, and provides an overview of an abstract process, or building blocks, for conducting interpretivist digital government research.

Furthermore, taking into account the proposed interpretivist philosophy for digital government, it is possible to offer some initial insights into the core concepts or research areas for interpretivist digital government studies. These 
following insights are not meant to be all-encompassing, but, rather should offer a starting point for future discussion and investigation:

1. Interpretivist digital government research is systemic in nature and, therefore, it is important to understand the systemic interactions at play.

2. Digital government means something different to different people, it is only by talking, studying, and understanding the beliefs associated with digital government that one can begin to explain specific actions associated with digital government. This would imply that there is a different understanding about the actual nature of digital government across contexts, and, indeed, across stakeholder groups.

3. Digital government is in a constant state of co-evolution. As the environment changes it influences the beliefs and values of humans, similarly, as humans make choices and actions it influences the environment. Thus, digital government is not something static, but, rather, it is a dynamic and constantly evolving object.

Looking towards the future, it is likely to be the case that digital government will continue to evolve as society and technology both change digital government, and are, simultaneously, changed by it. The job is up to us, as scholars of digital government, to ensure that our theoretical and philosophical knowledge is able to provide the necessary and needed ability to understand these changes and generate new knowledge for the benefit of society. Here it is important to emphasize that for understanding it is not enough to simply describe changes or actions; as researchers, it is paramount that we strive to truly understand that which we study. It is only through this understanding that knowledge and explanation can follow, and this happens via a process of analyzing, researching, and interpreting. As technology becomes increasingly important in our modern day society, and as government continues to evolve towards a more digital form, having researchers with the necessary capability to interpret and understand these changes can only be of a benefit. Thus, it is hoped that, moving forwards, there will be increased interest and development of the interpretivist paradigm of digital government research. 


\section{References}

Akrich, M. (1992). The de-scription of technical objects. In W. E. . Bijker \& J. Law (Eds.), Shaping Technology/Building Society, ed. Bijker and Law (pp. 205-224).

Aldiabat, K. M., \& Le Navenec, C. (2011). Philosophical Roots of Classical Grounded Theory: Its Foundations in Symbolic Interactionism. The Qualitative Report, 16(4), 1063-1080. http://nsuworks.nova.edu/tqr/vol16/iss4/9

Andrade, A. D., \& Urquhart, C. (2010). The affordances of actor network theory in ICT for development research. Information Technology \& People, 23(4), 352-374. https://doi.org/10.1108/09593841011087806

Anthopoulos, L., Reddick, C. G., Giannakidou, I., \& Mavridis, N. (2016). Why e-government projects fail? An analysis of the Healthcare.gov website. Government Information Quarterly, 33(1), 161-173. https://doi.org/10.1016/j.giq.2015.07.003

Apolitical. (2019). Digital Government: The 100 Most Influential People 2019. Apolitical. https://apolitical.co/lists/digital-government-world100/. Last accessed: 30 Oct. 2020.

Bannister, F., \& Connolly, R. (2015). The great theory hunt: Does e-government really have a problem? Government Information Quarterly, 32(1), 1-11. https://doi.org/10.1016/j.giq.2014.10.003

Bevir, M., \& Rhodes, R. A. W. (2003). Interpreting British Governance. Psychology Press.

Blumer, H. (1969). Symbolic Interactionism: Perspective and Method. Prentice-Hall.

Butler, T. (1998). Towards a hermeneutic method for interpretive research in information systems. Journal of Information Technology, 13(4), 285-300. https://doi.org/10.1057/jit.1998.7

Callon, M. (1984). Some Elements of a Sociology of Translation: Domestication of the Scallops and the Fishermen of St Brieuc Bay. The Sociological Review, 32(1_suppl), 196-233. https://doi.org/10.1111/j.1467954X.1984.tb00113.x

Castells, M. (1996). The rise of the network society (1st ed.). Blackwell Publishers.

Castells, M. (1998). The Information Age: Economy, Society and Culture. Wiley-Blackwell.

Castells, M. (2002). The Internet Galaxy: Reflections on the Internet, Business, and Society. Oxford University Press.

Devadoss, P. R., Pan, S. L., \& Huang, J. C. (2003). Structurational analysis of e-government initiatives: A case study of SCO. Decision Support Systems, 34(3), 253-269.

Doty, D. H., \& Glick, W. H. (1994). Typologies As a Unique Form Of Theory Building: Toward Improved Understanding and Modeling. Academy of Management Review, 19(2), 230-251. https://doi.org/10.5465/amr.1994.9410210748

Draheim, D., McBride, K., Misnikov, Y., Hartleb, F., Lauk, M., Lekme, F., Nagumo, T., \& Pappel, I. (2020, January). On the Narratives and Background Narratives of e-Government. In Proceedings of the 53rd Hawaii International Conference on System Sciences.

Dunleavy, P., \& O'Leary, B. (1987). Theories of the State: The Politics of Liberal Democracy. Red Globe Press.

Eisenhardt, K. M. (1989). Building Theories from Case Study Research. Academy of Management Review, 14(4), 532-550. https://doi.org/10.5465/amr.1989.4308385

Fairclough, N. (2013). Critical Discourse Analysis. In J. P. Gee \& M. Handford (Eds.), The Routledge Handbook of Discourse Analysis (1st ed.). Routledge.

Fountain, J. (2006). Central issues in the political development of the virtual state. In M. Castells \& G. Cardoso (Eds.), The Network Society: From Knowledge to Policy (pp. 149-181). Center for Transatlantic Relations, Johns Hopkins U.-SAIS. 
Fountain, J. E. (2001). Building the virtual state : information technology and institutional change. Brookings Institution Press.

Ganapati, S., \& Reddick, C. G. (2012). Open e-government in U.S. state governments: Survey evidence from Chief Information Officers. Government Information Quarterly, 29(2), 115-122. http://www.sciencedirect.com/science/article/pii/S0740624X12000056

Giddens, A. (1984). The Constitution of Society: Outline of the Theory of Structuration. University of California Press.

Giddens, A. (1987). The Nation-State and Violence: Volume 2 of A Contemporary Critique of Historical Materialism. University of California Press.

Glaser, B. G., \& Strauss, A. L. (1967). The Discovery of Grounded Theory: Strategies for Qualitative Research. Aldine de Gruyter.

Goldkuhl, G. (2004). Meanings of pragmatism: Ways to conduct information systems research. Action in Language, Organisations and Information Systems.

Goldkuhl, G. (2012). Pragmatism vs interpretivism in qualitative information systems research. European Journal of Information Systems, 21(2), 135-146. https://doi.org/10.1057/ejis.2011.54

Goldkuhl, G. (2016). E-government design research: Towards the policy-ingrained IT artifact. Government Information Quarterly, 33(3), 444-452. https://doi.org/10.1016/j.giq.2016.05.006

Gregor, S. (2006). The nature of theory in Information Systems. MIS Quarterly: Management Information Systems, 30(3), 611-642. https://doi.org/10.2307/25148742

Gruber, T. (2009). Ontology. In Encyclopedia of Database Systems (pp. 1963-1965). Springer US. https://doi.org/10.1007/978-0-387-39940-9_1318

Hay, C. (2011). Interpreting Interptretivism Interpreting Interpretations: The New Hermeneutics of Public Administration. Public Administration, 89(1), 167-182. https://doi.org/10.1111/j.1467-9299.2011.01907.x

Hay, C., Lister, M., \& Marsh, D. (2006). The State: Theories and Issues. Palgrave Macmillan.

Heeks, R., \& Bailur, S. (2007). Analyzing e-government research: Perspectives, philosophies, theories, methods, and practice. Government Information Quarterly, 24(2), 243-265. http://www.sciencedirect.com/science/article/B6W4G-4KNKBTC-1/2/687a115b56b46f452f5ada4fe10948c8

Heeks, R., \& Stanforth, C. (2007). Understanding e-Government project trajectories from an actor-network perspective. European Journal of Information Systems, 16(2), 165-177. https://doi.org/10.1057/palgrave.ejis.3000676

Janks, H. (1997). Critical discourse analysis as a research tool. Discourse, 18(3), 329-342. https://doi.org/10.1080/0159630970180302

Jones, M. R., \& Karsten, H. (2008). Giddens's structuration theory and information systems research. In MIS Quarterly: Management Information Systems (Vol. 32, Issue 1, pp. 127-157). Management Information Systems Research Center. https://doi.org/10.2307/25148831

Joseph, R. C. (2013). A structured analysis of e-government studies : Trends and opportunities. Government Information Quarterly, 30(4), 435-440. https://doi.org/10.1016/j.giq.2013.05.006

King, R. (1986). The State in Modern Society. In The State in Modern Society. Palgrave. https://doi.org/10.1007/978-1-349-18269-5

Klein, H. K., \& Myers, M. D. (1999). A set of principles for conducting and evaluating interpretive field studies in information systems. MIS Quarterly: Management Information Systems, 23(1), 67-94. https://doi.org/10.2307/249410

Latour, B. (1996). On actor-network theory: A few clarifications. In Soziale Welt (pp. 369-381). Nomos 
Verlagsgesellschaft mbH. https://doi.org/10.2307/40878163

Lazarsfeld, P. F., \& Rosenberg, M. (1955). The Language of Social Research: A Reader in the Methodology of Social Research. Free Press.

Lee, J., \& Kim, J. (2007). Grounded theory analysis of e-government initiatives: Exploring perceptions of government authorities. Government Information Quarterly, 24(1), 135-147. https://doi.org/10.1016/j.giq.2006.05.001

Lips, M. (2012). E-Government is dead: Long live Public Administration 2.0. Information Polity: The International Journal of Government \& Democracy in the Information Age, 17(3), 239-250. http://dx.doi.org/10.3233/IP120292

Madison, G. B. (1988). The Hermeneutics of Postmodernity: Figures and Themes. Indiana University Press.

Marshall, P., Kelder, J.-A., \& Perry, A. (2005). Social Constructionism with a Twist of Pragmatism: A Suitable Cocktail for Information Systems Research. 16 Th Australasian Conference on Information Systems, 1-7.

McBride, K. (2020). Open Government Data Co-Created Public Services [Tallinn University of Technology]. https://digikogu.taltech.ee/et/Item/e75082ae-9115-48c0-9526-09466e8a6698

McBride, K., \& Draheim, D. (2020). On Complex Adaptive Systems and Electronic Government: A Proposed Theoretical Approach for Electronic Government Studies. Electronic Journal of e-Government, 18(1).

Meijer, A., \& Bekkers, V. (2015). A metatheory of e-government: Creating some order in a fragmented research field. Government Information Quarterly, 32(3), 237-245. https://doi.org/10.1016/J.GIQ.2015.04.006

Mergel, I., Edelmann, N., \& Haug, N. (2019). Defining digital transformation: Results from expert interviews. Government Information Quarterly, 36(4), 101385. https://doi.org/10.1016/j.giq.2019.06.002

Merriam, S. B. (1998). Qualitative research and case study applications in education. Jossey-Bass Publishers.

Merriam, S. B. (2002). Introduction to Qualitative Research. In Qualitative Research in Practice: Examples for Discussion and Analysis (pp. 1-17). Wiley.

Miller, D. (2003). Political Philosophy: A Very Short Introduction. Oxford University Press. https://global.oup.com/ushe/product/political-philosophy-a-very-short-introduction9780192803955?cc=ee\&lang=en\&

Molnar, A., Janssen, M., \& Weerakkody, V. (2015). e-Government Theories and Challenges: Findings from a Plenary Expert Panel. Proceedings of the 16th Annual International Conference on Digital Government Research (Dg.o 2015), 160-166. https://doi.org/10.1145/2757401.2757419

Nam, T. (2014). Determining the type of e-government use. Government Information Quarterly, 31(2), 211-220. https://doi.org/10.1016/j.giq.2013.09.006

Niehaves, B. (2011). Iceberg ahead: On electronic government research and societal aging. Government Information Quarterly, 28(3), 310-319. https://doi.org/10.1016/j.giq.2011.01.003

Norris, D. F. (2003). Building the Virtual State ... or Not? A Critical Appraisal. Social Science Computer Review, 21(4), 417-424. https://doi.org/10.1177/0894439303256728

Norris, D. F. (2010). E-Government 2020: Plus ça change, plus c'est la meme chose. Public Administration Review, 70, s180-s181. https://doi.org/10.1111/j.1540-6210.2010.02269.x

Peters, B. G., \& Pierre, J. (2006). Governance, government and the state. In C. Hay, M. Lister, \& D. March (Eds.), The state: theories and issues (pp. 209-221). HarperCollins.

Poole, M. S., \& DeSanctis, G. (2011). Structuration Theory in Information Systems Research. In The Handbook of Information Systems Research (pp. 206-249). IGI Global. https://doi.org/10.4018/978-1-59140-144-5.ch013

Puron-Cid, G. (2013). Interdisciplinary application of structuration theory for e-government: A case study of an IT- 
enabled budget reform. Government Information Quarterly, 30(SUPPL. 1), S46-S58. https://doi.org/10.1016/j.giq.2012.07.010

Reinwald, A., \& Kraemmergaard, P. (2012). Managing stakeholders in transformational government - A case study in a Danish local government. Government Information Quarterly, 29(2), 133-141. http://www.sciencedirect.com/science/article/pii/S0740624X1200007X

Rheingold, H. (1993). The Virtual Community: Homesteading on the Electronic Frontier (1st ed.). HarperCollins.

Rubin, H. J., \& Rubin, I. S. (2011). Chapter 2: Research Philosophy and Qualitative Interviews. In Qualitative Interviewing: The Art of Hearing Data (3rd ed., p. 288). SAGE.

Samier, E. (2005). Toward a Weberian Public Administration: The Infinite Web of History, Values, and Authority in Administrative Mentalities. Halduskultuur: Administrative Culture, 60-93.

Scholl, Hans. J. (2010). Electronic Government: A study Domain Past Its Infancy. In Hans. J Scholl (Ed.), EGovernment: Information, Technology, and Transformation (Vol. 17, pp. 11-32). M.E. Sharpe.

Scholl, Hans J. (2007). Discipline or interdisciplinary study domain? Challenges and Promises in Electronic Government Research. In H. Chen (Ed.), Digital Government (pp. 19-40). Springer.

Scholl, Hans J. (2016). Making Sense of Indices and Impact Numbers: Establishing Leading EGOV Scholars' "Signatures." In Hans Jochen Scholl, O. Glassey, M. Janssen, B. Klievink, I. Lindgren, P. Parycek, E. Tambouris, M. A. Wimmer, T. Janowski, \& D. Sa Soares (Eds.), Electronic Government: Proceedings of the 15th IFIP WG 8.5 International Conference, EGOV 2016 (pp. 3-18). Springer International Publishing.

Scholl, Hans J. (2014). The EGOV Research Community: An Update on Where We Stand. In M. Janssen, H. J. Scholl, M. A. Wimmer, \& F. Bannister (Eds.), Electronic Government: Proceedings of the 13th IFIP WG 8.5 International Conference, EGOV 2014 (Vol. 8653, pp. 1-16). http://link.springer.com/chapter/10.1007/978-3662-44426-9_1

Schwandt, T. A. (1993). Constructivist, interpretivist approaches to human inquiry. In N. K. Denzin \& Y. S. Lincoln (Eds.), Handbook of qualitative research (pp. 118-137). Sage Publications.

Shyu, S. H. P., \& Huang, J. H. (2011). Elucidating usage of e-government learning: A perspective of the extended technology acceptance model. Government Information Quarterly, 28(4), 491-502. https://doi.org/10.1016/j.giq.2011.04.002

Stanforth, C. (2007). Using Actor-Network Theory to Analyze E-Government Implementation in Developing Countries. Information Technologies and International Development, 3(3), 35-60. https://doi.org/10.1162/itid.2007.3.3.35

Strauss, A. L., \& Corbin, J. M. (1998). Basics of qualitative research : techniques and procedures for developing grounded theory (2nd ed.). Sage Publications.

Tursunbayeva, A., Franco, M., \& Pagliari, C. (2017). Use of social media for e-Government in the public health sector: A systematic review of published studies. Government Information Quarterly, 34(2), 270-282. https://doi.org/10.1016/j.giq.2017.04.001

Walsham, G. (1995). Interpretive case studies in IS research: Nature and method. European Journal of Information Systems, 4(2), 74-81. https://doi.org/10.1057/ejis.1995.9

Walsham, G. (1997). Actor-Network Theory and IS Research: Current Status and Future Prospects. In Information Systems and Qualitative Research (pp. 466-480). Springer US. https://doi.org/10.1007/978-0-387-35309-8_23

Wang, Y. S., \& Shih, Y. W. (2009). Why do people use information kiosks? A validation of the Unified Theory of Acceptance and Use of Technology. Government Information Quarterly, 26(1), 158-165. https://doi.org/10.1016/j.giq.2008.07.001

Webster;, M.-. (2020). Transform | Definition of Transform by Merriam-Webster. Merriam - Webster. https://www.merriam-webster.com/dictionary/transform. Last accessed: 30 Oct. 2020. 
Webster, F. (2006). Theories Of The Information Society (1st ed.). Routledge.

Webster, F. (2014). Theories of the Information Society. In Theories of the Information Society (4th ed.). Routledge. https://doi.org/10.4324/9781315867854

Wicks, A. C., \& Freeman, R. E. (1998). Organization Studies and the New Pragmatism: Positivism, Anti-positivism, and the Search for Ethics. Organization Science, 9(2), 123-140. https://doi.org/10.1287/orsc.9.2.123

Wodak, R. (2014). Critical discourse analysis. In C. Leung \& B. V. Street (Eds.), The Routledge Companion to English Studies (pp. 332-346). Routledge. https://doi.org/10.4324/9781315852515-29

Yazan, B. (2015). The Qualitative Report Three Approaches to Case Study Methods in Education: Yin, Merriam, and Stake. In The Qualitative Report (Vol. 20, Issue 2). http://www.nova.edu/ssss/QR/QR20/2/yazan1.pdf

Yildiz, M, \& Saylam, A. (2013). E-government discourses: An inductive analysis. Government Information Quarterly, 30(2), 141-153. https://doi.org/10.1016/j.giq.2012.10.007

Yildiz, Mete. (2007). E-government research: Reviewing the literature, limitations, and ways forward. Government Information Quarterly, 24(3), 646-665. https://doi.org/10.1016/j.giq.2007.01.002

Yin, R. K. (2018). Case Study Research and Applications Design and Methods (6th ed.). Sage Publications. 